\title{
LATENT EFFECTS OF SOME PESTICIDES AND PLANT GROWTH REGULATOR ON COWPEA APHID, Aphis craccivora KOCH (HOMOPTERA: APHIDIDAE) \\ Hashem, H. H. A. ${ }^{* *}$; I. F. Shokry ${ }^{*}$; K. T. Hussein ${ }^{*}$ and Rehab M. El-Gendy \\ * Fac. Sci., Zagazig Univ., Egypt. \\ ** Plant Protection Res. Institute, Agric. Res. Center, Giza, Egypt.
}

\begin{abstract}
The latent toxicity of chemical insecticide; malathion, bioinsecticide; Beauveria bassiana and a plant growth regulator (PGR) Extratone were studied on some biological parameters of adult Aphis craccivora under laboratory conditions. The obtained results revealed that the two sub-lethal concentration 0.01 and $0.1 \mathrm{ppm}$ sub $\mathrm{LC}_{50}(0.73 \mathrm{ppm})$ of malathion decreased each of the mean longevity of adult (one day old), mean offspring in addition to pre-parturition, parturition and post-parturition periods in comparison to the control. Eventually, both concentrations reduced the mean numbers of offspring of adult per day. B. bassiana at concentrations (200ppm) at (100ppm) decreased each of the mean longevity of adult, number of offspring, preparturition and parturition but increased post-parturition periods in comparison to the control. Both concentrations of $B$. bassiana treatment reduced the mean number of offspring of $A$. craccivora (one day old) during longevity per day. Extratone at recommended concentration decreased the duration of $A$. craccivora, increased the pre-parturition period and decreased the parturition period, Post-parturition period, the mean longevity of $A$. craccivora and the mean number of offspring of each $A$. craccivora adult female.
\end{abstract}

Keywords: Aphis craccivora, malathion, Beauveria bassiana, plant growth regulator

(PGR), Extratone, pre-parturition, parturition, post-parturition periods

\section{INTRODUCTION}

The cowpea aphid, Aphis craccivora is one of the major insect pest attacking leguminous crops in Egypt. Malathion is the most effective insecticide in controlling this pest as it posses a highly toxic effect against $A$. craccivora (Nasser et al., 2000). Entomopathogenic fungi are currently used in controlling several insect pests as an alternative way or complementary to chemical insecticides. Improvements in virulence and speed of killing can be achieved by understanding the mechanisms of fungal pathogenesis and using genetically modifying targeted genes, thus improving the commercial efficacy of these biocontrol agents. Entomopathogenic fungi are considered as the best candidate for biological control of aphid (Latge and Papierok, 1988; Van et al., 2007). Plant growth regulators proved to have different effects on $A$. craccivora. The aim of the present work is determining the latent effect of some pesticides of different types on cowpea aphid. 
Hashem, H. H. A. et al.

\section{MATERIALS AND METHODS}

Tested compounds:

Chemical insecticide:

-Trade name: Malathion57\% (EC).

-Chemical name: o,o-dimethyl-s-(1,2(di-carbethoxy ethyl phosphoro dithioate)).

-Recommended rate: $1.250 \mathrm{~L} /$ Feddan.

Entomopathogenic fungus:

- Trade name: Biovar.

- Scientific name: Beauveria bassiana.

- Recommended rate: $200 \mathrm{~g} / 100 \mathrm{~L}$ at concentration of $2.3 \times 10^{7}$ spores per gm.

Plant growth regulator:

- Trade name: Extratone.

- Chemical compistion: It consists of

Napthylacetic acid............2.5\%
Moisture.....................5.0\%
Inert.................... $92.5 \%$

-Recommended rate: $60 \mathrm{~cm} / 100 \mathrm{~L}$.

Rearing technique of $A$. craccivora:

$A$. craccivora were reared on faba bean plants under laboratory conditions at $20-25 c^{\circ}, 70+5 \%$ R.H. and under a photoperiod of $16: 18$ hours according to El-Arnaouty (1991).

Biochemical assays:

Treatments:

Malathion 57\% E.C.:

The two concentrations of aqueous solution were prepared at $(0.01$ and $0.1 \mathrm{ppm})$, respectively under $\mathrm{LC}_{50}(0.73 \mathrm{ppm})$ after determination it and five replicates were used for each concentration, each replicate have 20 individuals of $A$. craccivora.

Beauveria bassiana:

The two concentrations of aqueous solution were prepared (100 and $200 \mathrm{ppm}$ ), respectively and five replicates were used for each concentration, each replicate have 20 individuals of $A$. craccivora.

Plant growth regulator (PGR), Extratone treatments:

Five replicates were prepared at recommended concentration (60 $\mathrm{ml} / 100 \mathrm{~L}$ ), each replicate have 20 individuals of $A$. craccivora.

Application technique:

Leaf dipping technique:

The serial concentrations of aqueous solution were prepared for each tested insecticides. Leaves of faba bean were dipped in the insecticides solutions for 10 second then left to dry at room temperature. Treated leaves were put separately in five Petri dishes for each concentration and untreated leaves put in five Petri dish as control then 20 individuals of $A$. craccivora were put in each replicate and counted individuals after 24, 48, $72 \mathrm{hr}$. post treatments under laboratory conditions $\left(25-28^{\circ} \mathrm{C}\right.$ and $70-75 \mathrm{R} . \mathrm{H} \%$.) (Ghatwary, 2000) and followed them daily, then latent effect was determined as mean longevity of adult, pre-parturition, parturition, Post-parturition, the mean number of nymphs/female and the mean number of offspring of adult stage. 


\section{RESULTS AND DISCUSSION}

Latent effect of malathion $57 \% \mathrm{EC}$ at different sub lethal concentrations (LC50s) on biological aspects of adult stage of Aphis craccivora (one day old):

Data represented in Table (1) show that, the two sub-lethal concentrations $\mathrm{LC}_{50 \mathrm{~s}}$ of malathion decreased the mean longevity of adult as compared with the control. The mean longevity of adult ranged between $8.23 \pm 0.62$ and $8.47 \pm 0.63$ days and control was $11.91 \pm 0.64$ days. The obtained data also show decrease in mean offspring at $0.1 \mathrm{ppm}$ gave $14.46 \pm 1.5$ nymphs and at $0.01 \mathrm{ppm}$ gave $21.46 \pm 1.61$ nymphs while control gave $35.25 \pm 1.83$ nymphs. Also, pre-parturition, parturition and postparturition periods changed compared with control.

The pre-parturition periods which the adult don't able to give offspring increased than control for the two concentrations as follow at $0.1 \mathrm{ppm}$ and $0.01 \mathrm{ppm}$ showed $1.38 \pm 0.14,1.2 \pm 0.11$ day, respectively and control was $1.10 \pm 0.03$ day. The parturition periods of $A$. craccivora at $0.1 \mathrm{ppm}, 0.01 \mathrm{ppm}$ concentration of malathion decreased than control which were $6.07 \pm 0.62$, $6.00 \pm 0.55$ and $10.60 \pm 0.61$ days, respectively. The mean post-parturition periods were $0.77 \pm 0.3,1.27 \pm 0.21$ and $0.28 \pm 0.08$ days at $0.1 \mathrm{ppm}, 0.01 \mathrm{ppm}$ and control, respectively. The increase in the mean post-parturition period which the adult still alive and don't able give progenies was observed.

The results indicated highly latent effects of malathion These results are in harmony with these results recorded by (Islam et al., 1990) who stated that malathion $57 \%$ EC was most effective causing a $99.26 \%$ reduction of aphids. (Chang and Chen, 1993) who found that controlled of $A$. craccivora effectively by malathion $50 \%$ EC.

Table (1): Latent effect of malathion $57 \%$ EC. at different sub lethal concentrations $\mathrm{LC}_{50}$ ) on biological aspects of adult stage of A.craccivora under laboratory conditions.

\begin{tabular}{|c|c|c|c|c|c|}
\hline $\begin{array}{c}\text { Concentrations } \\
\text { ppm }\end{array}$ & $\begin{array}{c}\text { Longivety } \\
\text { Mean+S.E. } \\
\text { (Day) }\end{array}$ & $\begin{array}{c}\text { Pre- } \\
\text { parturition } \\
\text { Mean } \pm \text { S.E. } \\
\text { (Day) }\end{array}$ & $\begin{array}{c}\text { Parturition } \\
\text { Mean+S.E. } \\
\text { (Day) }\end{array}$ & $\begin{array}{c}\text { Post- } \\
\text { Parturition } \\
\text { Mean } \pm \text { S.E. } \\
\text { (Day) }\end{array}$ & $\begin{array}{c}\text { No. } \\
\text { of nymphs/ } \\
\text { female } \\
\text { Mean+S.E. } \\
\text { (Day) }\end{array}$ \\
\hline 0.01 & $\begin{array}{c}8.47+0.63 \\
(5-11)\end{array}$ & $\begin{array}{c}1.2 \pm 0.11 \\
(1-2)\end{array}$ & $\begin{array}{c}6.00 \pm 0.55 \\
(3-8)\end{array}$ & $\begin{array}{c}1.27 \pm 0.21 \\
(0-2)\end{array}$ & $\begin{array}{c}21.46 \pm 1.61 \\
(12-33)\end{array}$ \\
\hline 0.1 & $\begin{array}{c}8.22 \pm 0.62 \\
(6-11)\end{array}$ & $\begin{array}{c}1.38 \pm 0.14 \\
(1-2)\end{array}$ & $\begin{array}{c}6.07 \pm 0.62 \\
(3-10)\end{array}$ & $\begin{array}{c}0.77 \pm 0.30 \\
(0-3)\end{array}$ & $\begin{array}{c}14.46 \pm 1.5 \\
(7-23)\end{array}$ \\
\hline Control & $\begin{array}{c}11.91 \pm 0.64 \\
(4-24)\end{array}$ & $\begin{array}{c}1.10 \pm 0.03 \\
(1-2)\end{array}$ & $\begin{array}{c}10.60 \pm 0.61 \\
(3-23)\end{array}$ & $\begin{array}{c}0.28 \pm 0.08 \\
(0-3)\end{array}$ & $\begin{array}{c}35.25 \pm 1.83 \\
(5-65)\end{array}$ \\
\hline
\end{tabular}

Effect of malathion on number of offspring of adult stage of Aphis craccivora ne day old during longevity at different sub-lethal concentrations under laboratory conditions:

Data presented in Table (2) show the daily mean number of offspring of $A$. craccivora per female for two sub lethal concentrations of malathion. 
Hashem, H. H. A. et al.

The obtained data show that, in the first, second, third, fourth, fifth, sixth, seventh, eighth and ninth day the mean number of nymphs were $(1.25 \pm 0.16, \quad 3.60 \pm 0.43, \quad 4.27 \pm 0.29, \quad 3.85 \pm 0.22, \quad 3.13 \pm 0.44, \quad 2.44 \pm 0.18$, $2.71 \pm 0.29,2.60 \pm 0.81 \& 1.00 \pm 0.00)$ at $0.01 \mathrm{ppm},(1.00 \pm 0.00,3.31 \pm 0.31$, $3.07 \pm 0.28,3.62 \pm 0.25,1.91 \pm 0.21,1.00 \pm 0.00,1.00 \pm 0.00,1.4 \pm 0.24$ \& zero) at $0.1 \mathrm{ppm}$ and recorded in control $(4.15 \pm 0.45,4.67 \pm 0.26,5.06 \pm 0.58$, $6.13 \pm 0.32,3.81 \pm 0.19,3.56 \pm 0.17,3.16 \pm 0.20,3.67 \pm 0.16 \& 2.6 \pm 0.18)$ nymphs, respectively.

On the tenth day the mean numbers of nymphs were zero, zero and $2.17 \pm 0.31$ nymphs at $0.01 \mathrm{ppm}, 0.1 \mathrm{ppm}$ and control, respectively. Finely on the eleventh day the mean numbers of nymphs were zero, zero and $2.20 \pm 0.34$ nymphs at $0.01 \mathrm{ppm}, 0.1 \mathrm{ppm}$ and control, respectively. Generally, all the two sub lethal concentrations of malathion treatment reduced the mean numbers of progenies of apterous as compared to control.

Table (2): Effect of malathion on number of offspring of adult stage of $A$. craccivora ne day old during longevity at different sub-lethal concentrations under laboratory conditions.

\begin{tabular}{|c|c|c|c|}
\hline \multirow[b]{2}{*}{ Days } & \multicolumn{3}{|c|}{ Concentrations } \\
\hline & $\begin{array}{c}0.01 p p m \\
\text { Mean+S.E. }\end{array}$ & $\begin{array}{c}0.1 p p m \\
\text { Mean+S.E. }\end{array}$ & $\begin{array}{c}\text { Control } \\
\text { Mean+S.E. }\end{array}$ \\
\hline $1^{s t}$ & $\begin{array}{c}1.25 \pm 0.16 \\
(1-2)\end{array}$ & $\begin{array}{c}1.00+0.00 \\
(1-1)\end{array}$ & $\begin{array}{c}4.15 \pm 0.45 \\
(1-9)\end{array}$ \\
\hline $2^{n d}$ & $\begin{array}{c}3.60 \pm 0.43 \\
(1-5)\end{array}$ & $\begin{array}{c}3.31 \pm 0.31 \\
(2-5)\end{array}$ & $\begin{array}{c}4.67 \pm 0.26 \\
(2-7)\end{array}$ \\
\hline $3^{r d}$ & $\begin{array}{c}4.27 \pm 0.29 \\
(2-7)\end{array}$ & $\begin{array}{c}3.07 \pm 0.28 \\
(2-4)\end{array}$ & $\begin{array}{c}5.06 \pm 0.58 \\
(2-8)\end{array}$ \\
\hline $4^{t h}$ & $\begin{array}{c}3.85 \pm 0.22 \\
(3-5)\end{array}$ & $\begin{array}{c}3.62 \pm 0.25 \\
(2-6)\end{array}$ & $\begin{array}{c}6.13 \pm 0.32 \\
(5-8)\end{array}$ \\
\hline $5^{t h}$ & $\begin{array}{c}3.13 \pm 0.44 \\
(1-4)\end{array}$ & $\begin{array}{c}1.91 \pm 0.21 \\
(1-3)\end{array}$ & $\begin{array}{c}3.81 \pm 0.19 \\
(2-6)\end{array}$ \\
\hline $6^{t h}$ & $\begin{array}{c}2.44 \pm 0.18 \\
(2-3)\end{array}$ & $\begin{array}{c}1.00 \pm 0.00 \\
(1-1)\end{array}$ & $\begin{array}{c}3.56 \pm 0.17 \\
(2-5)\end{array}$ \\
\hline $7^{t h}$ & $\begin{array}{c}2.71 \pm 0.29 \\
(2-4)\end{array}$ & $\begin{array}{c}1.00 \pm 0.00 \\
(1-1)\end{array}$ & $\begin{array}{c}3.16 \pm 0.20 \\
(2-5)\end{array}$ \\
\hline $8^{t h}$ & $\begin{array}{c}2.60 \pm 0.81 \\
(2-4)\end{array}$ & $\begin{array}{c}1.4 \pm 0.24 \\
(1-2)\end{array}$ & $\begin{array}{c}3.67 \pm 0.16 \\
(2-5)\end{array}$ \\
\hline $9^{t h}$ & $\begin{array}{c}1.00 \pm 0.00 \\
(1-1)\end{array}$ & $\begin{array}{c}0.00 \pm 0.00 \\
(0-0)\end{array}$ & $\begin{array}{c}2.6 \pm 0.18 \\
(1-4)\end{array}$ \\
\hline $10^{t h}$ & $\begin{array}{c}0.00 \pm 0.00 \\
(1-1)\end{array}$ & $\begin{array}{c}0.00 \pm 0.00 \\
(0-0)\end{array}$ & $\begin{array}{c}2.17 \pm 0.31 \\
(1-5)\end{array}$ \\
\hline $11^{t h}$ & $\begin{array}{c}0.00 \pm 0.00 \\
(0-0)\end{array}$ & $\begin{array}{c}0.00 \pm 0.00 \\
(0-0)\end{array}$ & $\begin{array}{c}2.20 \pm 0.34 \\
(1-4)\end{array}$ \\
\hline
\end{tabular}

Latent effect of Beauveria bassiana (Biovar) at sub recommended concentration on biological aspects of adult stage of Aphis craccivora (one day old):

Entomopathogenic fungi, $B$. bassiana, penetrate the insect cuticle utilizing a plethora of hydrolytic enzymes, including chitinases, which are important virulence factors. Two chitinases (Bbchit 1 and Bbchit 2) have 
previously been characterized in $B$. bassiana, neither of which possesses chitin-binding domains.

The obtained data in Table (3) reveal that (200ppm) and (100ppm) decreased the mean longevity of apterous, number of offspring and three division periods of duration of $A$. craccivora adult as compared to control, respectively.

The data show decrease in the longevity, offspring of apterous adult of $A$. craccivora, decrease in pre- parturition and parturition periods than control and this will resulted in a decrease of the injury the aphids caused to faba bean. Also the increase in post-parturition periods than control was observed.

The obtained data proved that $B$. bassiana can serve successfully as a biocontrol agent against $A$. craccivora. These results are in harmony with these results obtained by (Zaki, 1998) who revealed that, $B$. bassiana was effective in controlling $A$. craccivora, the period of reproduction of $A$. craccivora was significantly decreased after applying. The total duration was decreased by increasing the dose of the compound.

Baverstock et al. 2006 stated that the infection by $B$. bassiana reduced the number of nymphs produced of $A$. pisum within $24 \mathrm{~h}$ of inoculation and over the entire infection period compared to uninfected aphids. Kim, 2007 revealed that, a significant dose of $V$. lecanii affect on reduction of life span, reproductive period and fecundity in $1^{\text {st }}$ and $3^{\text {rd }}$ instars after spore application. Reproduction period was also significantly shortened with increasing spore concentration. It was the isolate which able to affect populations of cotton aphid by reducing life span and total fecundity.

Table (3): Latent effect of $B$. bassiana (Biovar) at two concentrations 100 and $200 \mathrm{ppm}$ on biological aspects of adult stage of $A$. craccivora (one day old) under laboratory conditions.

\begin{tabular}{|c|c|c|c|c|c|}
\hline $\begin{array}{c}\text { Concentrations } \\
\text { Ppm }\end{array}$ & $\begin{array}{c}\text { Longevity/ } \\
\text { day } \\
\text { Period } \\
\text { Mean } \pm \text { S.E. }\end{array}$ & $\begin{array}{c}\text { Pre- } \\
\text { parturition } \\
\text { Period } \\
\text { Mean } \pm \text { S.E. }\end{array}$ & 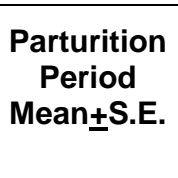 & $\begin{array}{c}\text { Post- } \\
\text { Parturition } \\
\text { Period } \\
\text { Mean } \pm \text { S.E. }\end{array}$ & $\begin{array}{c}\text { No of } \\
\text { nymphs/ } \\
\text { female } \\
\text { Mean } \pm \text { S.E. }\end{array}$ \\
\hline 100 & $\begin{array}{c}9.91 \pm 1.31 \\
(5-18)\end{array}$ & $\begin{array}{c}1.00 \pm 0.00 \\
(1-1)\end{array}$ & $\begin{array}{c}7.91 \pm 0.93 \\
(4-11)\end{array}$ & $\begin{array}{c}1.00 \pm 0.55 \\
(0-6)\end{array}$ & $\begin{array}{c}31.55 \pm 2.36 \\
(16-41)\end{array}$ \\
\hline 200 & $\begin{array}{c}8.33 \pm 0.66 \\
(4-15)\end{array}$ & $\begin{array}{c}1.00 \pm 0.00 \\
(1-1)\end{array}$ & $\begin{array}{c}6.57 \pm 0.49 \\
(1-10)\end{array}$ & $\begin{array}{c}0.76 \pm 0.28 \\
(0-4)\end{array}$ & $\begin{array}{c}27.43 \pm 1.62 \\
(14-39)\end{array}$ \\
\hline $\mathbf{C}$ & $\begin{array}{c}11.91 \pm 0.64 \\
(4-24)\end{array}$ & $\begin{array}{c}1.10 \pm 0.03 \\
(1-2)\end{array}$ & $\begin{array}{c}10.60 \pm 0.61 \\
(3-23)\end{array}$ & $\begin{array}{c}0.28 \pm 0.08 \\
(0-3)\end{array}$ & $\begin{array}{c}35.25+1.83 \\
(5-65)\end{array}$ \\
\hline
\end{tabular}


Hashem, H. H. A. et al.

Effect of Beauveria bassiana (Biovar) on number of offspring of adult stages of Aphis craccivora (one day old) during longevity at two concentrations under laboratory conditions:

The data presented in Table (4) show the mean number of progenies (nymphs) of $A$. craccivora during longevity per female daily at two tested concentration of $B$. bassiana (100ppm) and (200ppm). Data show that female gave mean on first day zero nymphs at $100 \mathrm{ppm}$ and $200 \mathrm{ppm}$ while gave $4.15 \pm 0.45$ nymphs at control. On the second day female gave $5.6 \pm 0.15$, $4.67 \pm 0.26$ and $6.45 \pm .64$ nymphs at $100 \mathrm{ppm}, 200 \mathrm{ppm}$ and control respectively. On the third day female gave $4.55 \pm 0.43,4.27 \pm 0.29$ and $5.00 \pm 0.23$ nymphs at $100 \mathrm{ppm}, 200 \mathrm{ppm}$ and control, respectively.

Table (4): Effect of Beauveria bassiana Balsamo on number of offspring of dult stages of Aphis craccivora (one day old) during longevity at two tested concentrations 100 and 200 ppm under laboratory conditions:

\begin{tabular}{|c|c|c|c|}
\hline \multirow[b]{2}{*}{ Days } & \multicolumn{3}{|c|}{ Concentrations } \\
\hline & $\begin{array}{c}\text { 100ppm } \\
\text { Mean士S.E. } \\
\text { (Ranges) }\end{array}$ & $\begin{array}{c}\text { 200ppm } \\
\text { Mean+S.E. } \\
\text { (Ranges) }\end{array}$ & $\begin{array}{c}\text { Control } \\
\text { Mean } \pm \text { S.E. } \\
\text { (Ranges) }\end{array}$ \\
\hline $1^{s t}$ & $\begin{array}{c}0.00 \pm 0.00 \\
(0-0)\end{array}$ & $\begin{array}{c}0.00 \pm 0.00 \\
(0-0)\end{array}$ & $\begin{array}{c}4.15 \pm 0.45 \\
(1-9)\end{array}$ \\
\hline $2^{n d}$ & $\begin{array}{c}5.60 \pm 0.15 \\
(5-7)\end{array}$ & $\begin{array}{c}4.67 \pm 0.26 \\
(2-7)\end{array}$ & $\begin{array}{c}6.45 \pm 0.64 \\
(4-9)\end{array}$ \\
\hline $3^{r d}$ & $\begin{array}{c}4.55 \pm 0.43 \\
(3-6)\end{array}$ & $\begin{array}{c}4.27 \pm 0.29 \\
(2-7)\end{array}$ & $\begin{array}{c}5.00 \pm 0.23 \\
(3-6)\end{array}$ \\
\hline $4^{t h}$ & $\begin{array}{c}4.82 \pm 0.54 \\
(3-7)\end{array}$ & $\begin{array}{c}3.62 \pm 0.25 \\
(2-6)\end{array}$ & $\begin{array}{c}6.10 \pm 0.21 \\
(5-7)\end{array}$ \\
\hline $5^{t h}$ & $\begin{array}{c}3.81 \pm 0.19 \\
(2-6)\end{array}$ & $\begin{array}{c}2.78 \pm 0.10 \\
(2-3)\end{array}$ & $\begin{array}{c}4.91 \pm 0.10 \\
(4-5)\end{array}$ \\
\hline $6^{\text {th }}$ & $\begin{array}{l}3.56 \pm 0.17 \\
(2-5)\end{array}$ & $\begin{array}{c}3.20 \pm 0.12 \\
(2-4)\end{array}$ & $\begin{array}{c}3.89 \pm 0.45 \\
(3-5)\end{array}$ \\
\hline $7^{\text {th }}$ & $\begin{array}{c}3.16 \pm 0.20 \\
(2-5)\end{array}$ & $\begin{array}{c}2.50 \pm 0.19 \\
(2-3)\end{array}$ & $\begin{array}{c}3.64 \pm 0.13 \\
(3-5)\end{array}$ \\
\hline $8^{t h}$ & $\begin{array}{c}3.10 \pm 0.16 \\
(2-4)\end{array}$ & $\begin{array}{c}2.69 \pm 0.13 \\
(2-3)\end{array}$ & $\begin{array}{c}4.17 \pm 0.54 \\
(2-5)\end{array}$ \\
\hline $9^{t h}$ & $\begin{array}{c}2.6 \pm 0.18 \\
(1-4)\end{array}$ & $\begin{array}{c}1.80 \pm 0.20 \\
(1-2)\end{array}$ & $\begin{array}{c}3.00+0.55 \\
(1-4)\end{array}$ \\
\hline $10^{t h}$ & $\begin{array}{c}2.40 \pm 0.24 \\
(2-3)\end{array}$ & $\begin{array}{c}1.40 \pm 0.24 \\
(1-2)\end{array}$ & $\begin{array}{c}3.20 \pm 0.34 \\
(1-5)\end{array}$ \\
\hline $11^{\text {th }}$ & $\begin{array}{c}2.00 \pm 0.00 \\
(2-2)\end{array}$ & $\begin{array}{c}1.25 \pm 0.25 \\
(1-2)\end{array}$ & $\begin{array}{c}2.17 \pm 0.31 \\
(1-5)\end{array}$ \\
\hline $12^{t h}$ & $\begin{array}{c}0.00 \pm 0.00 \\
(0-0)\end{array}$ & $\begin{array}{c}11140.00 \pm 0.00 \\
(0-0)\end{array}$ & $\begin{array}{c}2.43 \pm 0.17 \\
(1-3)\end{array}$ \\
\hline
\end{tabular}


On the fourth day female gave $4.82 \pm 0.54,3.62 \pm 0.25$ and $6.10 \pm 0.21$ nymphs, on the fifth day female gave $3.81 \pm 0.19,2.78 \pm 0.10$ and $4.91 \pm 0.10$ nymphs, on sixth day female gave $3.56 \pm 0.17,3.20 \pm 0.12$ and $3.89 \pm 0.45$ nymphs, on seventh day female gave $3.16 \pm 0.20,2.5 \pm 0.19$ and $3.64 \pm 0.13$ nymphs, on eighth day female gave $3.10 \pm 0.16,2.69 \pm 0.13$ and $4.17 \pm 0.54$ nymphs, on ninth day female gave $2.6 \pm 0.18,1.80 \pm 0.20$ and $3.00 \pm 0.55$ nymphs, On tenth day female gave $2.40 \pm 0.24,1.40 \pm 0.24$ and $3.20 \pm 0.34$ nymphs, on eleventh day female give $2.00 \pm 0.00,1.25 \pm 0.25$ and $2.17 \pm 0.31$ nymphs and on twelveth day female gave zero, zero and $2.43 \pm 0.17$ nymphs at 100ppm, 200ppm and control, respectively.

Generally, both concentrations of $B$. bassiana reduced the mean number of progenies of apterous compared with control. These results are in agreement with (Zaki, 1998) who revealed that, B. bassiana was effective in controlling $A$. craccivora and the fecundity was reduced markedly from 95.7 young in the control to 3.4 young at $0.05 \mathrm{mg}$. ml-1. But (Kim, 2007) investigated that the daily fecundity of individual aphids, A. gossypii was not affected by spore dose of $V$. lecanii CS625.

Effect of Extratone as a plant growth regulator on biological aspects of Aphis craccivora at recommended concentration:

The obtained data in Table (5) show that the recommended concentration of Extratone affected the duration of $A$. craccivora by increasing the pre-parturition period. The pre-parturition period was $1.25 \pm 0.16$ day for Extratone, while control was $1.10 \pm 0.03$ day.

Table (5): Comparison between effects of treatments with malathion at $\mathrm{LC}_{50}(0.73 \mathrm{ppm}), B$. bassiana and Extratone at recommended concentration on biological aspects of $\boldsymbol{A}$. craccivora adults under laboratory conditions:

\begin{tabular}{|c|c|c|c|c|c|}
\hline Periods & $\begin{array}{c}\text { Longevity/day } \\
\text { Period } \\
\text { Mean } \pm \text { SE) }\end{array}$ & $\begin{array}{c}\text { Pre- } \\
\text { parturition } \\
\text { Period } \\
\text { Mean } \pm \text { SE }\end{array}$ & $\begin{array}{c}\text { Parturition } \\
\text { Period } \\
\text { Mean } \pm \text { SE }\end{array}$ & $\begin{array}{c}\text { Post- } \\
\text { Parturition } \\
\text { Period } \\
\text { Mean } \pm \text { SE }\end{array}$ & $\begin{array}{c}\text { No. of } \\
\text { nymphs/ } \\
\text { female } \\
\text { Mean } \pm \text { SE }\end{array}$ \\
\hline Control & $11.91 \pm 0.64$ & $1.10 \pm 0.03$ & $10.60 \pm 0.61$ & $0.20 \pm 0.08$ & $35.25 \pm 1.83$ \\
$(4-24)$ & $(1-2)$ & $(3-23)$ & $(0-3)$ & $(5-65)$ \\
\hline Extratone & $7.13 \pm 0.67$ & $1.25 \pm 0.16$ & $5.88 \pm 0.72$ & $0.00 \pm 0.00$ & $12.50 \pm 2.05$ \\
& $(5-18)$ & $(1-2)$ & $(3-9)$ & $(0-0)$ & $(5-21)$ \\
\hline Malathion & $5.88 \pm 0.69$ & $1.00 \pm 0.00$ & $4.25 \pm 0.49$ & $0.63 \pm 0.26$ & $13.38 \pm 1.63$ \\
& $(4-9)$ & $(1-1)$ & $(3-6)$ & $(0-2)$ & $(4-20)$ \\
\hline Beauvaria & $8.33 \pm 0.66$ & $1.00 \pm 0.00$ & $6.57 \pm 0.49$ & $0.76 \pm 0.28$ & $27.43 \pm 1.62$ \\
bassiana & $(4-15)$ & $(1-1)$ & $(1-10)$ & $(0-4)$ & $(14-39)$ \\
\hline
\end{tabular}

Extratone decreased the parturition period $(5.88 \pm 0.72)$ days while control $(10.60 \pm 0.61)$ days. Post-parturition period was zero for Extratone, recorded $0.20 \pm 0.08$ days in case of control. Also, the obtained data show decrease in the mean longevity of $A$. craccivora, $(7.13 \pm 0.67)$ days after applying Extratone at recommended concentration, while it was $(11.91 \pm 0.64)$ days in control. Just as the data show decrease in the mean number of offspring of each mother of $A$. craccivora when treated with Extratone at 
recommended concentration $(12.50 \pm 2.05)$ nymphs while the control was $35.25 \pm 1.83$ nymphs.

This result indicated that Extratone used to improve faba bean growth and also control $A$. craccivora. The results represented in Table (5) also indicated highly efficiency of malathion than other treatments.

\section{REFERENCES}

Baverstock, J.; H. E. Roy; S. J. Clark; P. G. Alderson and J. K. Pell (2006): Effect of fungal infection on the reproductive potential of aphids and their progeny. J. of Invert. Patholo., 91(2): 136-139.

Chang, D. C. and C. C. Chen (1993): Population fluctuation of major insect pests on kidney bean and the proper time of control. Bull. Taich. District. Agric. Improvement. Stat., (38): 11-22.

El-Arnaouty, S.A. (1991): Studies on the biology and manipulation of Chrysoperla carnea (Stephens) and Chrysoperla sinica (Tjeder) (Neuroptera: Chrysopedae) for controlling the green peach aphids Myzus persicae (Sulzer) (Homoptera: Aphididae) in greenhouses Ph. D. Thesis, Faculty of Agric., Cairo Univer.

Ghatwary, W. G. T. (2000): Integrated management of certain piercing sucking insects infesting some vegetables crops. PH. D. Thesie Fac. Agric Zagazig. Uni., 1-227 pp.

Islam, N. M.; I. M. Buiyah and M. A. Karim (1990): Field evaluation of some insecticides for the control of the mustared aphid. Bangladesh $\mathrm{J}$. Zool., 18(2): 261-262.

Kim, J. (2007): Influence of Verticillium lecanii on the development and reproduction of the cotton aphid, Aphis gossypii. BioControl., 52(6): 789-799.

Latge, J.P. and B. Papierok (1988): Aphid pathogens, pp.323-336. In: Minks,A.K. and Harrewijin , P. (Eds.), Aphids. Their biology, natural enemies and control. Vol. 2B. Elservier Science, Amesterdam.

Nasser, M. A. K; A. M. EL-Ghareeb; A. M. K. EL-Sayed and G. A. Mohamed (2000): Toxicological effects of some insecticides against susceptible and field population of the cowpea aphid, Aphis craccivora (Koch). Assiut. J. Agric. Sci., 31(1)217-230.

Van, H. V.; S. Hong and K. Kim (2007): Selection of entomopathogenic fungi for aphid control.J. of Biosci. and Bioengineering, 104(6): 498-505.

Zaki, F. N. (1998): Efficiency of the entomopathogenic fungus, Beauvaria bassiana (Rals), against Aphis craccivora Koch and Bemisia tabaci, Gennadius. J. App. Entomol., 122(7):397-399.

التأثيرات المتأخرة لبعض المبيدات و منظمات النمو النباتية علي حشرة من اللوبيا 


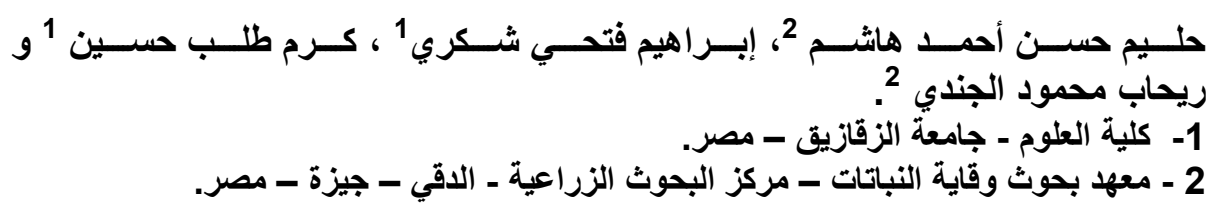

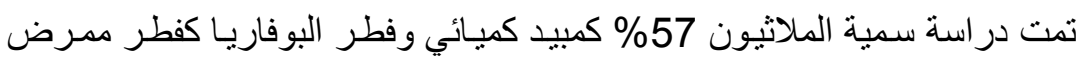

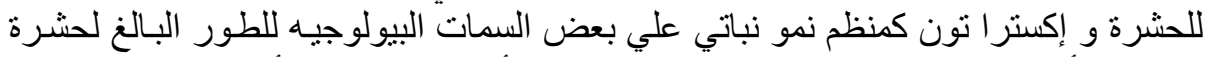

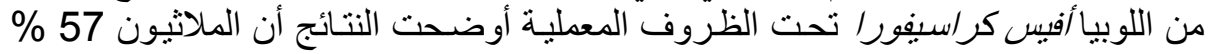

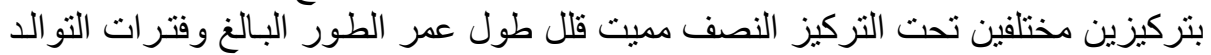

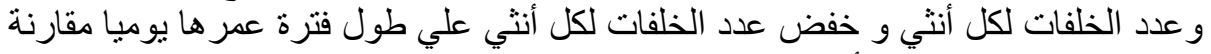

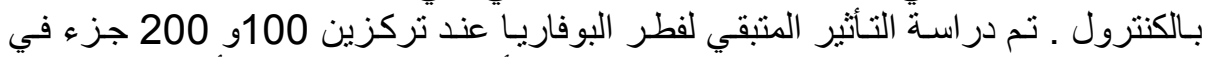

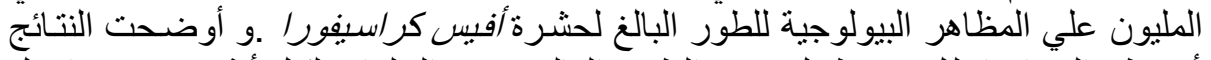

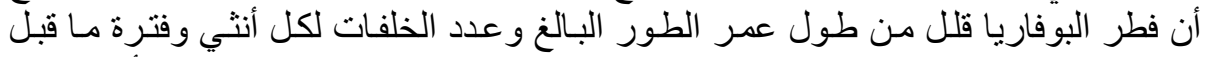

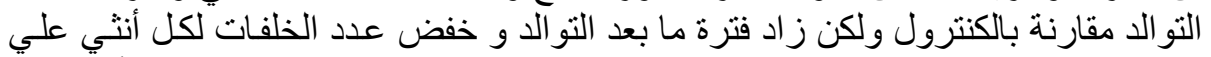

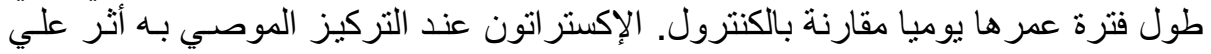

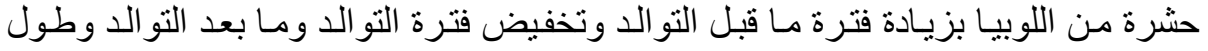
عمر هاو منوسط عدد الخلفات لكل حشرة كاملة.

$$
\text { كلية الزراعة - جامعة المنصورة }
$$

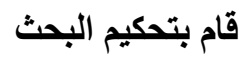 \\ أ.ـد / ليلى عبد الستار البطران البحان

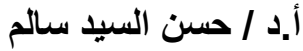

